\title{
Adolescents Are More Vulnerable to Cocaine Addiction: Behavioral and Electrophysiological Evidence
}

\author{
Wai Chong Wong, Kerstin A. Ford, Nicole E. Pagels, James E. McCutcheon, and Michela Marinelli \\ Department of Cellular and Molecular Pharmacology, Rosalind Franklin University of Medicine and Science, The Chicago Medical School, North Chicago, \\ Illinois 60064
}

In humans, adolescence is a period of heightened propensity to develop cocaine addiction. It is unknown whether this is attributable to greater access and exposure to cocaine at this age, or whether the adolescent brain is particularly vulnerable to the addictive properties of cocaine. Here, we subjected male adolescent $(\mathrm{P} 42)$ and adult $(\sim \mathrm{P} 88)$ rats to a wide range of cocaine self-administration procedures. In addition, to determine whether behavioral differences are associated with developmental differences in dopaminergic activity, we examined and manipulated the activity of dopamine neurons. Relative to adults, adolescent rats took cocaine more readily, were more sensitive to lower doses, showed greater escalation of cocaine intake, and were less susceptible to increases in price (i.e., were more "inelastic"). In parallel, adolescents also showed elevated activity of ventral tegmental area dopamine neurons, a feature known to be associated with increased self-administration behavior. Pharmacological manipulation of dopamine $\mathrm{D}_{2}$ receptor function with quinpirole (agonist) or eticlopride (antagonist), to alter dopamine neuron activity, eliminated age differences in cocaine self-administration. These data suggest a causal relationship between behavioral and electrophysiological determinants of cocaine addiction liability. In conclusion, adolescents show behavioral and electrophysiological traits of heightened addiction liability.

\section{Introduction}

Adolescence is a period of heightened propensity to develop cocaine addiction in humans (Kandel et al., 1992; Chambers et al., 2003; Johnston et al., 2011), as manifested by more rapid disease progression and more severe symptoms (Anthony and Petronis, 1995; Patton et al., 2004; Reboussin and Anthony, 2006; Chen et al., 2009). It is unclear whether such heightened susceptibility results from greater drug exposure and experimentation or whether adolescents are more sensitive to the addictive properties of cocaine. To determine this in humans is difficult because one cannot account for differences in drug-taking opportunities across ages. Equally, it is impossible to study cocaine use in the absence of nonbiological factors, such as the socioeconomic influences on drug use.

Using animal models, we can study drug intake under conditions of equal drug access. Although no single behavioral task can model every element of addiction, different self-administration

Received March 8, 2012; revised Dec. 28, 2012; accepted Jan. 26, 2013.

Author contributions: W.C.W., J.E.M., and M.M. designed research; W.C.W., K.A.F., N.E.P., and M.M. performed research; W.C.W., K.A.F., N.E.P., J.E.M., and M.M. analyzed data; W.C.W., J.E.M., and M.M. wrote the paper.

This work was supported by National Institutes of Health Grant R01DA020654. We thank Mitch Beales and Lorissa Lamoureux for technical assistance, Dr. Serge Ahmed for helpful input on the escalation procedures, and Dr. Robert Messing for helpful comments on this manuscript. We thank Dr. Dave Moody and personnel at the Center for Human Toxicology at University of Utah for analyzing brain cocaine levels, with the support of National Institute on Drug Abuse Contract N01DA-9-7767. We thank Dr. Pete Roma of the Institutes for Behavior Resources (www.ibrinc.org) for his advice on data analysis using the Exponential Model of Demand.

The authors declare no competing financial interests.

Correspondence should be addressed to Michela Marinelli, Department of Cellular and Molecular Pharmacology, Rosalind Franklin University of Medicine and Science, The Chicago Medical School, 3333 Green Bay Road, North Chicago, IL 60064. E-mail: mickymarinelli@gmail.com.

J. E. McCutcheon's present address: Department of Psychology, University of Illinois at Chicago, Chicago, IL 60607.

DOI:10.1523/JNEUROSCI.1371-12.2013

Copyright $\odot 2013$ the authors $\quad 0270-6474 / 13 / 334913-10 \$ 15.00 / 0$ procedures can model specific aspects of drug-taking (for review, see Lynch and Carroll, 2001). Current literature shows that, compared with adult rats, adolescent rats take more of certain drugs of abuse (Schramm-Sapyta et al., 2009), such as alcohol (Doremus et al., 2005; Siegmund et al., 2005), nicotine, and amphetamine (Levin et al., 2007; Shahbazi et al., 2008). However, studies on cocaine are inconsistent and, unfortunately, have only used single-dose acquisition procedures. Some studies show that adolescents have greater intake than adults (Anker and Carroll, 2010; Schramm-Sapyta et al., 2011), whereas others show that adolescents and adults do not differ (Leslie et al., 2004; Belluzzi et al., 2005; Frantz et al., 2007; Kantak et al., 2007; Kerstetter and Kantak, 2007; Harvey et al., 2009; Li and Frantz, 2009). To address these discrepancies, here we used a wide array of cocaine doses and self-administration procedures to model multiple dimensions of drug-taking, namely, intake and sensitivity [acquisition of self-administration, using short (ShA)/long (LgA) access procedures], escalation of intake, and cocaine consumption as a function of price (cocaine intake when the ratio to obtain the drug is increased). Using these procedures, we found that, relative to adult rats, adolescent rats exhibited heightened cocaine self-administration behavior.

Heightened cocaine self-administration is associated with heightened activity of ventral tegmental area (VTA) dopamine neurons in adult rats (Marinelli and White, 2000). Interestingly, the activity of dopamine neurons is also heightened during adolescence (McCutcheon and Marinelli, 2009; McCutcheon et al., 2012). We sought to establish causality between behavioral and physiological measures of addiction liability by administering drugs that modify dopamine neuron activity, during cocaine selfadministration. Specifically, we tested the hypothesis that de- 
A Cocaine dose 0
$(\mu \mathrm{g} / \mathrm{kg} /$ infusion $)$

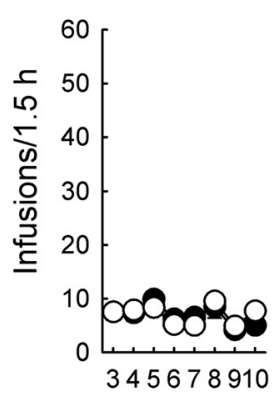

300
B
75

150

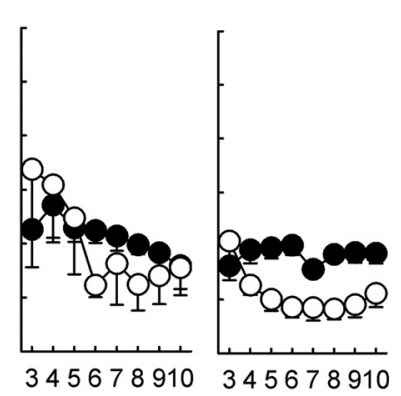

- Adolescent

Adolescent (pre-pubertal)

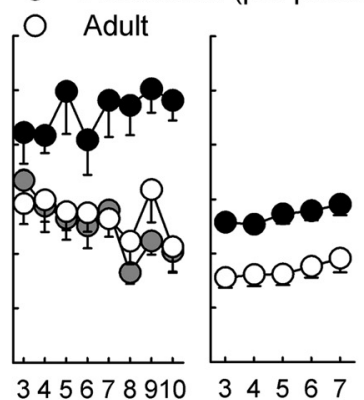

345678910

Days of self-administration

600

1200

B

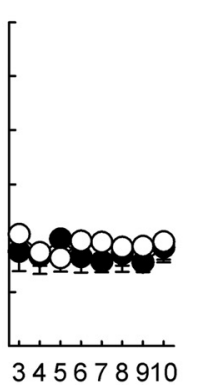

345678910

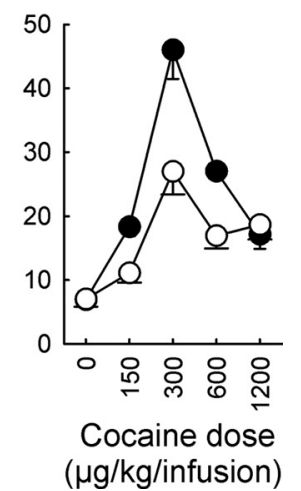

Figure 1. Acquisition of cocaine self-administration behavior across cocaine doses. A, Intake of saline or cocaine at a very low (75 $\mu \mathrm{g} / \mathrm{kg}$ per infusion), low (150 $\mu \mathrm{g} / \mathrm{kg}$ per infusion), moderately low (300 $\mu \mathrm{g} / \mathrm{kg}$ per infusion), moderate (600 $\mu \mathrm{g} / \mathrm{kg}$ per infusion), or high (1200 $\mu \mathrm{g} / \mathrm{kg}$ per infusion) dose during daily ShA ( $1.5 \mathrm{~h})$. Each point represents the mean \pm SEM of each group in each of the $1.5 \mathrm{~h}$ self-administration sessions. Adolescents $(n=6,8,8,16,20$, and 12) and adults $(n=6,8,9,11,18$, and 13) at doses $0,75,150,300,600$, and $1200 \mu \mathrm{g} / \mathrm{kg}$ per infusion, respectively; $n=14$ for prepubertal adolescents at the dose of $300 \mu \mathrm{g} / \mathrm{kg}$ per infusion. $\boldsymbol{B}$, Acquisition of cocaine self-administration at various doses of cocaine in adolescents relative to adults. Each point represents mean \pm SEM of the last 3 self-administration days at doses shown in $A$.

creasing heightened dopamine neuron activity in adolescent rats will decrease their elevated cocaine intake to levels observed in adults; conversely, increasing dopamine neuron activity in adults will increase their cocaine intake to levels observed in adolescents.

\section{Materials and Methods \\ Subjects}

Male Sprague Dawley rats were obtained from the Portage colony (Charles River). They were housed three per cage under a $12 \mathrm{~h}$ light/dark cycle, at a constant temperature of $22 \pm 2^{\circ} \mathrm{C}$ and humidity of $66 \% \pm 25$, with ad libitum access to food and water at all times. Adolescent rats were weaned at exactly postnatal day 21 (P21). All rats arrived in the vivarium $\sim 1$ week before starting experiments. During this acclimation time, rats were handled at least once. Onset of puberty was determined from approximately P35 to P44 using the balano-preputial separation method (Kolho et al., 1988); it occurred at approximately P41. All experiments lasted 7-10 d unless specified and were started when prepubertal adolescent rats, postpubertal adolescent rats (called "adolescent rats" hereafter), and adult rats were at P35, P42, and P88, respectively. All studies were performed during the dark phase of the light/dark cycle, when rats are active. Studies were performed over a $\sim 2$ year period.

\section{Cocaine self-administration}

Rats tested for cocaine self-administration or experimenter-imposed cocaine infusions received intravenous catheterization of the right external jugular vein under anesthesia with isoflurane gas (5\% induction, $2-3 \%$ maintenance). A SILASTIC catheter (10-12 $\mu$ l dead volume) was secured to the jugular vein and passed subcutaneously to exit the midscapular region. During the postoperative recovery period of $\sim 1$ week, the catheter was flushed daily with sterile saline $(100 \mu \mathrm{l})$ to prevent clogging. On the day before the start of self-administration sessions, rats were placed in self-administration chambers $(41 \times 24 \mathrm{~cm}$ floor area, 21 $\mathrm{cm}$ high; MED Associates) for habituation to the chambers for $1.5 \mathrm{~h}$. This was done to prevent exploratory behavior from interfering with selfadministration behavior. In a pilot experiment, we noted that adolescent rats explored the chamber more than adults and that this activity competed with self-administration behavior. Therefore, the habituation period served to remove this age bias.

The self-administration chambers were equipped with two nose-poke holes opposite each other, located $2 \mathrm{~cm}$ above the floor in each of the short sides of the chamber. The chambers were fitted inside a soundattenuating cubicle. During the acclimation period, nose-poke holes were covered. During self-administration, nose poking in one of the holes ("active" hole) delivered one drug infusion [i.e., fixed ratio 1 (FR1); one nose poke is equivalent to one infusion, unless otherwise stated]; it also resulted in illumination of a light inside the active hole for $10 \mathrm{~s}$. There was a 10-30 s timeout period to prevent overdosing in all experiments except for in the experiment that tested intake as a function of increasing ratio (price), which had no timeout. Nose poking in the other hole ("inactive") had no consequences. Infusions were delivered by a syringe pump at the volume of $200 \mu \mathrm{l} / \mathrm{kg}$ (i.e., $30 \mu \mathrm{l}$ for a $150 \mathrm{~g}$ rat) and a speed of $\sim 12 \mu \mathrm{l} / \mathrm{s}$. The number of nose pokes and the number of infusions were collected by MED Associates Software Package Schedule Manager for Windows. Patency of catheters was tested once per rat with Brevital (5 $\mathrm{mg} / \mathrm{kg}$, i.v.) toward the end of the experiment; rats that did not respond to the anesthetic immediately were eliminated from the studies. A total of 18 of $455(\sim 4 \%)$ rats were thus excluded from the studies.

Experiment 1: age differences in acquisition of self-administration $\operatorname{ShA}$. Different cohorts of rats were allowed to self-administer saline or cocaine (75-1200 $\mu \mathrm{g} / \mathrm{kg}$ per infusion) for $1.5 \mathrm{~h}$ daily for 7-10 $\mathrm{d}$. These cocaine doses are defined as very low ( $75 \mu \mathrm{g} / \mathrm{kg}$ per infusion), low (150 $\mu \mathrm{g} / \mathrm{kg}$ per infusion), moderately low (300 $\mu \mathrm{g} / \mathrm{kg}$ per infusion), moderate (600 $\mu \mathrm{g} / \mathrm{kg}$ per infusion), and high (1200 $\mu \mathrm{g} / \mathrm{kg}$ per infusion). Prepubertal adolescents were only tested at the moderately low dose $(300 \mu \mathrm{g} / \mathrm{kg}$ per infusion). Acquisition of self-administration behavior with cocaine at the moderate dose (600 $\mu \mathrm{g} / \mathrm{kg}$ per infusion) was also tested in a separate cohort of rats for the purpose of establishing an acquisition criterion.

$L g A$. To examine acquisition of drug taking when daily access to drugs was prolonged, a separate cohort of rats was allowed to self-administer cocaine for $6 \mathrm{~h}$ daily at a moderate dose $(600 \mu \mathrm{g} / \mathrm{kg}$ per infusion $)$ for $10 \mathrm{~d}$.

Experiment 2: age differences in escalation of cocaine self-administration

A separate cohort of rats was first trained to self-administer a moderate dose of cocaine $(600 \mu \mathrm{g} / \mathrm{kg}$ per infusion) for $4 \mathrm{~d}$ (twice daily, for eight $1.5 \mathrm{~h}$ sessions). Moderate-high doses are required to establish escalation (Ahmed and Koob, 1998; Mantsch et al., 2004). Because intake at moderate doses differed between adolescents and adults (Fig. 1) and this could influence subsequent escalation, we equalized the amount of cocaine intake across ages during the initial training phase. To do this, rats were removed from self-administration chambers once they reached 
15-20 infusions, or after a maximum of $3 \mathrm{~h}$. After the training phase, rats were subjected to the escalation study. For the escalation study, rats were tested 6 h daily (LgA) or 1.5 h daily (ShA) for $12 \mathrm{~d}$.

\section{Experiment 3: age differences in cocaine consumption as a function of price}

A separate cohort of rats was allowed to self-administer a high dose of cocaine (1200 $\mu \mathrm{g} / \mathrm{kg}$ per infusion) for $1.5 \mathrm{~h}$ daily. During the first $2 \mathrm{~d}$, we used an FR1 (one nose poke is equivalent to one infusion). The fixed ratio (i.e., the price) was then increased every other day (FR3, FR6, FR9, FR12, and FR24) so that rats completed two sessions at each price. Analysis was performed on the second session that rats completed at each price. The number of self-infusions (i.e., consumption) was fitted to the exponential demand curve established by Hursh and Silberberg (2008; Hursh and Roma, 2013): $\log Q=\log Q_{0}+k\left(e^{-\alpha\left(Q_{0} \times C\right)}-1\right)$. This curve is used to estimate the level of "motivation" to consume the drug (Hursh, 1993) and the manner in which cocaine intake resists increasing price (i.e., "elasticity of cocaine demand") (Bickel et al., 2000). Thus, it is considered a good method to evaluate abuse liability (Hursh, 1993). Q represents consumption (number of self-infusions), and $Q_{0}$ is the level of consumption at the lowest possible price. $C$ represents price (i.e., the ratio), and $k$ is set to a constant that accounts for the estimated range of consumption in logarithmic units ( $k=0.91$ in these studies). $\alpha$ is termed the "essential value" and represents elasticity of cocaine demand. Behavior is considered "inelastic" when consumption is insensitive to price (i.e., consumption is maintained despite increases in price), and it switches to "elastic" when consumption is sensitive to price (i.e., consumption declines with increases in price). A steeper decline equals more elastic behavior and a greater $\alpha$ (Hursh and Silberberg, 2008) relative to inelastic behavior. Using this equation, we can calculate $\mathrm{P}_{\max }$, which is the price at which behavior shifts from being inelastic to elastic (Bickel et al., 2000).

\section{Experiment 4: age differences in levels of cocaine and its metabolites}

A separate cohort of rats was allowed to self-administer a moderate dose of cocaine $(600 \mu \mathrm{g} / \mathrm{kg}$ per infusion) for $1.5 \mathrm{~h}$ daily for $2 \mathrm{~d}$. These initial self-administration sessions (days 1 and 2) were included to minimize any aversive effects caused by subsequent noncontingent cocaine infusions (Twining et al., 2009). Then, rats received 21 computer-delivered infusions of cocaine during $1.5 \mathrm{~h}$ daily sessions for the next $5 \mathrm{~d}$. Infusions were delivered at timed intervals, every $1.5 \mathrm{~min}$ for the first three infusions and every $5 \mathrm{~min}$ for the rest. The purpose of this design was to mimic a self-administration session while ensuring equal exposure to cocaine across groups. On the test day (day 7), rats were decapitated 2 min after receiving their last cocaine infusion. Trunk blood was collected in $5 \mathrm{ml}$ tubes containing sodium fluoride $(10 \mathrm{mg})$ and potassium oxalate $(8 \mathrm{mg})$; tubes were then stored at $-20^{\circ} \mathrm{C}$. After extraction and removal of the cerebellum, brains were fresh-frozen on dry ice and stored at $-80^{\circ} \mathrm{C}$. Samples were shipped to the University of Utah Center for Human Toxicology, where cocaine and metabolites (benzoylecgonine, ecgonine ethyl ester, norcocaine) were measured using liquid chromatographytandem mass spectrometry (Lin et al., 2001, 2003).

\section{In vivo extracellular recording of VTA dopamine neurons}

A separate cohort of rats was anesthetized with chloral hydrate $(400$ $\mathrm{mg} / \mathrm{kg}$, i.p.). A lateral tail vein was cannulated for intravenous administration of additional anesthetic or drugs. Rats were placed in a stereotaxic apparatus (David Kopf Instruments). Body temperature was monitored by a rectal thermometer (Medline Industries) and maintained at $37 \pm$ $0.5^{\circ} \mathrm{C}$ with a heating pad (Fintronics). We monitored the depth of anesthesia by ensuring absence of reaction to hindpaw pinch and ensuring breathing rates of $60-80$ breaths/min for adolescents and 52-72 breaths/ min for adults. In some experiments, measures of sleep-wake state were collected with cortical electroencephalograms to further ensure a stable state of anesthesia. A glass electrode was pulled from 2-mm-outerdiameter glass pipette, with a vertical electrode puller (Narishige PE-2) and broken under a microscope to a tip diameter of 1-2 $\mu \mathrm{m}$. The electrode was filled with $1 \%$ fast green dye (Thermo Fisher Scientific) in a $2 \mathrm{M}$
$\mathrm{NaCl}$ solution. The impedance of the electrode was 1.5-2.1 $\mathrm{M} \Omega$ measured at $135 \mathrm{~Hz}$ (Winston Electronics BL1000-B). A burr hole was drilled above the VTA (see below for coordinates). The electrode was lowered 5 or $6 \mathrm{~mm}$ ventral to cortical surface for adolescents and adults, respectively, and then slowly advanced into the region of dopamine neuron bodies with a hydraulic microdrive (David Kopf Instruments). Electrodes were lowered in the VTA region, along predefined "tracks" $(0.2$ $\mathrm{mm}$ apart); the area sampled in the adults was $3.2-4.0 \mathrm{~mm}$ anterior to lambda, $0.2-1.4 \mathrm{~mm}$ lateral from midline, and $7.5-8.5 \mathrm{~mm}$ ventral from cortical surface for adults. The area sampled in the adolescents was 2.4-3.4 $\mathrm{mm}$ anterior to lambda, $0.3-0.7 \mathrm{~mm}$ lateral from midline, and $7.5-8.5 \mathrm{~mm}$ ventral from cortical surface. These coordinates were scaled to yield similar final recording sites, despite differences in brain sizes across ages.

During extracellular recording of dopamine neurons, electrical signals were fed into a high-impedance amplifier (Fintronics), bandpass filtered at 400 and $500 \mathrm{~Hz}$ or at 50 and $800 \mathrm{~Hz}$, displayed on an oscilloscope (Tektronix R5110), and monitored by a window discriminator and an audio amplifier (Grass AM8; Grass Instruments). Digital outputs were fed through an interface (Digidata 1200 series; Molecular Devices) to a personal computer running AxoScope software (Molecular Devices), which determined firing activity online and stored all data for future analysis. Stored data were analyzed with a custom-made program that determines firing characteristics.

Dopamine neurons were identified by anatomical location in the VTA and according to standard physiological criteria (Bunney et al., 1973). Briefly, these criteria are as follows: a characteristic triphasic $(+/-/+)$ waveform with a long duration of 2.5-3.5 ms measured from start to end using $400-500 \mathrm{~Hz}$ filters or $>1.1 \mathrm{~ms}$ from beginning to trough of negative peak using $50-800 \mathrm{~Hz}$ filters. Firing patterns also show low spontaneous firing rates of $0.5-10 \mathrm{~Hz}$ (Grace and Bunney, 1984; Marinelli et al., 2006) with intermittent bursts, which are clusters of high-frequency spikes (Grace and Bunney, 1983). These criteria are $~ 90 \%$ accurate at detecting dopamine neurons (Ungless and Grace, 2012). To examine age-related differences in dopamine neuron activity, we collected a maximum of three to four cells per rat. Each recording consisted of at least 3 min of stable activity ( $<5 \%$ variation). We analyzed firing rate (spikes over time) and firing pattern. For the latter, the amount of bursting activity was calculated as the percentage of spikes emitted in bursts over the total number of spikes. We also calculated the frequency of burst events and the properties of the bursts (number of spikes/burst and burst duration in milliseconds).

At the end of the recording, rats were deeply anesthetized with additional chloral hydrate. The position of the electrode tip was marked by passing a $28 \mu \mathrm{A}$ cathodal current through the electrode for $\sim 30 \mathrm{~min}$. This deposited a discrete dye spot. Brains were then removed and stored in $10 \%$ Formalin until serial coronal sections $(40 \mu \mathrm{m})$ were cut on a freezing microtome (Leica Microsystems). Sections were mounted, and electrode placement was verified by light microscopy using in-house atlases for adolescent and adult rats of weights equivalent to those in this study. As up to four cells were recorded per rat, and only the final cell in each rat was marked by dye; locations of the other cells were extrapolated based on their recorded distance from the final cell. Given the difference in brain size across ages, we used a correction factor to extrapolate these distances in adolescents. This was calculated by comparing the length, width, and height of the midbrain across adolescent and adult brains. The correction factors were 1.14 for anteroposterior, 1.06 for mediolateral, and 1.09 for dorsoventral. We then verified that all cells were within the dopaminergic region of the VTA by mapping them on an additional in-house atlas showing dopaminergic regions of the VTA (immunohistochemical staining for tyrosine hydroxylase).

\section{Effects of drugs that modify dopamine neuron activity on cocaine self-administration}

A separate cohort of rats was allowed to self-administer a moderate dose of cocaine ( $600 \mu \mathrm{g} / \mathrm{kg}$ per infusion) for $1.5 \mathrm{~h}$ daily for $6 \mathrm{~d}$. During the first $2 \mathrm{~d}$, we used a FR1 (one nose poke is equivalent to one infusion). Then the FR was increased to 3 (three nose pokes are equivalent to one infusion) for the next $4 \mathrm{~d}$. Ten minutes before the beginning of the last session, rats received an injection of a drug that either increased or decreased mid- 
brain dopamine neuron activity, by acting on dopamine $\mathrm{D}_{2}$-class autoreceptors (henceforth called " $\mathrm{D}_{2}$ receptors"). Specifically, rats were given the $D_{2}$ receptor agonist quinpirole $[20 \mu \mathrm{g} / \mathrm{kg}$, s.c., an autoreceptorselective dose that decreases dopamine neuron activity (Marinelli et al., 2003)], the $D_{2}$ receptor antagonist eticlopride $[20 \mu \mathrm{g} / \mathrm{kg}$, s.c., a dose that increases dopamine neuron activity (Marinelli et al., 2003)], or saline (subcutaneously) as a control. Given that adolescents and adults show similar sensitivity of $\mathrm{D}_{2}$ receptors (McCutcheon et al., 2012), these pharmacological manipulations should result in similar effects on dopamine neuron firing rate across ages.

\section{Drugs}

Cocaine $\mathrm{HCl}$ was provided generously by the National Institute on Drug Abuse or purchased from Sigma-Aldrich and dissolved in a $0.9 \%$ saline solution; the $\mathrm{pH}$ of the solution was kept at $6.5-7.0$ with $0.1 \mathrm{~N} \mathrm{NaOH}$. Brevital, quinpirole hydrochloride, and eticlopride hydrochloride were purchased from Henry Schein and dissolved in 0.9\% saline solution. Isoflurane and $0.9 \%$ saline solution were purchased from Butler Schein. Chloral hydrate was purchased from Sigma-Aldrich and dissolved in deionized water.

\section{Statistical analyses}

Nose pokes and infusions were analyzed with ANOVA using, when appropriate, the between-subject factors of age (adolescents vs adults or prepubertal adolescents, adolescents, and adults), dose (saline vs cocaine), and access condition (ShA vs LgA), and the within-subject factors of hole (active vs inactive), days of training (different durations according to the experiment), fixed ratio (FR1, FR3, FR6, FR9, FR12, and FR24), and time point (pretreatment vs. posttreatment). Newman-Keuls test was used for post hoc analyses. The proportion of rats that reached acquisition was assessed with Fisher's exact test. Dopamine neuron activity was analyzed with Student's $t$ test (adolescents vs adults). Blood and brain levels of cocaine and its metabolites were also analyzed with Student's $t$ test (adolescents vs adults) unless samples were below the detection threshold; in this case, we used Mann-Whitney's $U$ test (adolescents vs adults). The above data were analyzed with Statistica (StatSoft). Elasticity of demand was analyzed with Prism 6 (GraphPad Software). Differences in the exponential demand curve values $Q_{0}$ and $\alpha$ were analyzed using an $F$ test (Cassidy and Dallery, 2012). The level of significance was 0.05 for all tests.

\section{Results}

\section{Cocaine self-administration}

Experiment 1: age differences in the acquisition of selfadministration

ShA. We compared self-administration behavior for saline and five doses of cocaine. For all doses, cocaine intake typically stabilized after $2 \mathrm{~d}$ of cocaine self-administration (data not shown); therefore, the acquisition profiles shown in Figure $1 A$ only include data from day 3 onward.

As Figure $1 A$ shows, adolescents and adults self-administered similar amounts of saline (age effect, $F_{(1,10)}=0.01$, n.s.), cocaine at a very low dose $\left(75 \mu \mathrm{g} / \mathrm{kg}\right.$ per infusion, age effect, $F_{(1,14)}=0.03$, n.s.), and cocaine at a high dose $(1200 \mu \mathrm{g} / \mathrm{kg}$ per infusion, age effect, $F_{(1,23)}=0.22$, n.s.). Adolescents self-administered more cocaine than adults at a low dose $(150 \mu \mathrm{g} / \mathrm{kg}$ per infusion, age effect, $\left.F_{(1,15)}=11.27, p<0.01\right)$, moderately low dose $(300 \mu \mathrm{g} / \mathrm{kg}$ per infusion, age effect, $\left.F_{(2,38)}=9.85, p<0.001\right)$, and a moderate dose $\left(600 \mu \mathrm{g} / \mathrm{kg}\right.$ per infusion, age effect, $F_{(1,36)}=19.83, p<$ $0.001)$. Prepubertal rats were also tested at the moderately low dose $(300 \mu \mathrm{g} / \mathrm{kg}$ per infusion). Intake differed according to age (age effect, $F_{(2,38)}=2.85, p<0.001$ ). Specifically, prepubertal adolescents and adults showed similar intake of cocaine (n.s.), whereas adolescents showed greater intake than both prepubertal adolescents and adults $(p<0.001)$. Figure $1 B$ shows average intake for each dose, over the last $3 \mathrm{~d}$ of self-administration at each dose. Direct group comparisons were not made because different doses were tested in separate experiments, across several months. The lowest dose $(75 \mu \mathrm{g} / \mathrm{kg}$ ) was not included because group averages were skewed by one adolescent rat and one adult rat exhibiting very high amounts of drug intake, as it often happens for very low doses. The figure illustrates the classical inverted U-shaped dose-response curve for cocaine self-administration (Lynch and Carroll, 2001) in both age groups.

We next examined whether adolescents acquire selfadministration more rapidly than adults by examining the proportion of rats that reached acquisition of cocaine selfadministration and the number of days that it took to reach acquisition. To perform this experiment, we established an acquisition criterion as proposed by Mitchell et al. (2005) using the trough of the bimodal distribution of responses on the active device, cumulated over all self-administration sessions. The trough represents a point of change in behavior, whereby rats responding less than the trough value have not yet learned the relationship between nose poking and reward, whereas rats responding more than the trough value have acquired the selfadministration behavior. We used a separate large cohort of rats (adolescents, $n=55$; adults, $n=58$ ), in which adolescents again showed greater intake than adults (Fig. $2 A$; age effect, $F_{(1,111)}=$ 26.89, $p<0.001$ ). Adults showed a bimodal distribution of nose poking, with a trough at 15 nose pokes. In contrast, adolescents did not show a bimodal distribution, because they lacked high proportions of low-response rates (Fig. 2C), suggesting more rapid acquisition of self-administration. In fact, using the acquisition criterion of 15 infusions, adolescents showed a faster and greater rate of acquisition than adults (Fig. 2B; Fisher's exact, two-tailed, $p=0.001)$. Furthermore, by the last day, $29 \%$ of adults failed to fulfill acquisition criteria as opposed to only $5 \%$ in adolescents. Therefore, adolescents were more likely than adults to acquire cocaine self-administration and to acquire it more rapidly.

$\operatorname{LgA}$. To ensure that differences in cocaine intake were not attributable to insufficient sampling time, we also compared the acquisition behavior of adolescent versus adult rats during LgA to cocaine self-administration. As Figure 3 shows, adolescents showed greater cocaine intake compared with adults in a LgA procedure ( $6 \mathrm{~h}$ sessions) (age effect, $F_{(1,19)}=25.45, p<0.001$; session effect, $F_{(9,171)}=9.89, p<0.001$; age $\times$ session interaction, $\left.F_{(9,171)}=3.41, p<0.001\right)$.

\section{Experiment 2: age differences on escalation of cocaine self- administration}

To equalize intake between groups, during the training sessions that preceded the escalation test, intake was limited to 15-20 infusions per session (Fig. $4 A$; age effect, $F_{(1,18)}=2.56$, n.s.; session effect, $F_{(7,126)}=3.53, p<0.01$; age $\times$ session interaction, $F_{(7,126)}=0.39$, n.s.). During these training sessions, adolescents were faster than adults at reaching 15-20 infusions (Fig. 4A, inset; $\left.t_{(20)}=-2.92, p<0.01\right)$. Rats were then divided into ShA and LgA groups, with similar intake during training (access condition effect, $F_{(1,18)}=0.006$, n.s.; age $\times$ group interaction, $F_{(1,18)}=0.12$, n.s.).

We first analyzed intake over $6 \mathrm{~h}$ in the LgA groups. As Figure $4 B$ shows, adolescents took more cocaine than adults overall (age effect, $F_{(1,9)}=12.27, p<0.01$ ); intake changed over time (session effect, $\left.F_{(11,99)}=6.76, p<0.001\right)$, and the relationship between age groups also changed over time (age $\times$ session interaction, $\left.F_{(11,99)}=8.31, p<0.001\right)$. In fact, escalation of cocaine intake was observed in adolescents (session effect in adolescents, $F_{(11,44)}=3.4$, 
A Cocaine (600 $\mu \mathrm{g} / \mathrm{kg} /$ infusion)

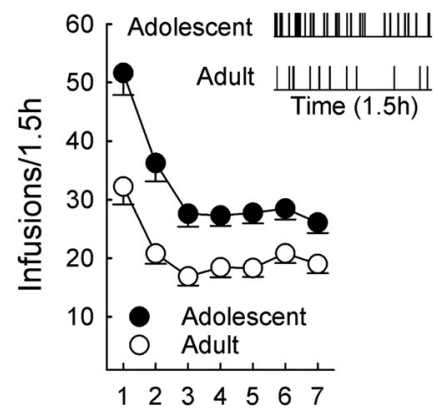

B Acquisition rate

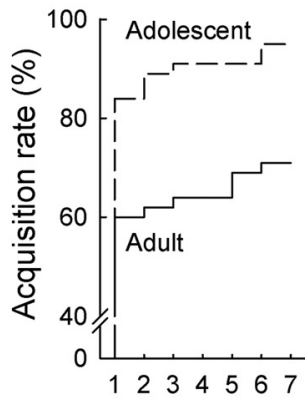

C
Adult

Days of self-administration

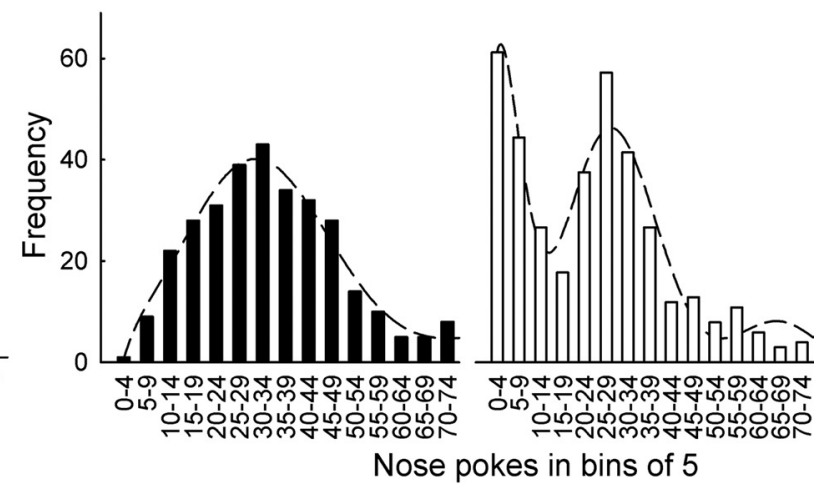

Figure 2. Acquisition pattern of cocaine self-administration at a moderate dose ( $600 \mu \mathrm{g} / \mathrm{kg}$ per infusion) during ShA ( $1.5 \mathrm{~h})$. $A$, Intake in the cohort used for the purpose of establishing the acquisition criteria. Each point represents the mean \pm SEM of each group in each of the $1.5 \mathrm{~h}$ self-administration sessions. Inset, Representative infusion records from an adolescent and an adult rat over a $1.5 \mathrm{~h}$ self-administration session. $\boldsymbol{B}$, Acquisition rate of cocaine self-administration. Lines represent percentage of rats that fulfilled acquisition criteria. $\boldsymbol{C}$, Distribution of nose pokes in the active hole during the acquisition of cocaine self-administration. The number of nose pokes from all rats and all sessions are binned in intervals of 5 . Bars are the number of active hole nose pokes at each particular bin interval. Adolescents, $n=55$; adults, $n=58$.

Cocaine

(600 $\mu \mathrm{g} / \mathrm{kg} /$ infusion)

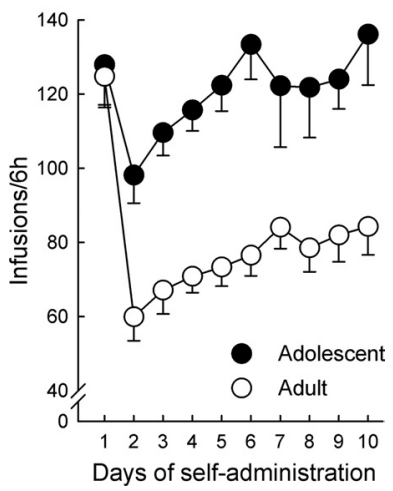

A

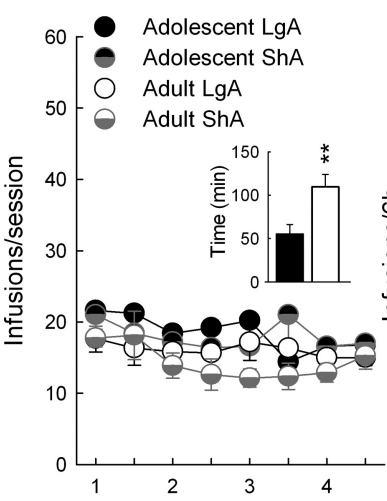

B

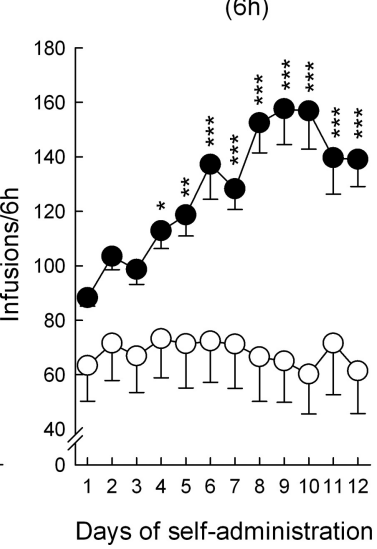

C Escalation

(1.5h)

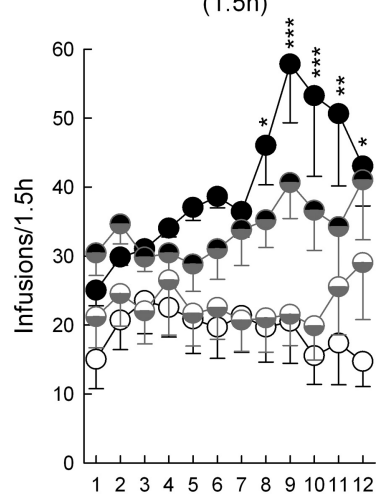

Figure 3. Acquisition of cocaine self-administration behavior at a moderate dose (600 $\mu \mathrm{g} / \mathrm{kg}$ per infusion) during $\mathrm{LgA}(6 \mathrm{~h})$. Each point represents the mean \pm SEM infusions of each group in each of the $6 \mathrm{~h}$ self-administration sessions. Adolescents, $n=9$; adults, $n=12$.

$p<0.002$ ) but not in adults (session effect in adults, $F_{(11,55)}=1.2$, n.s.). Specifically, cocaine intake in adolescents started to increase from session $4(p<$ 0.05 compared with session 1 ) and continued to increase thereafter (all $p$ values $<0.01$ ). On the contrary, cocaine intake in adults never increased (n.s. for all sessions vs session 1).

We then compared escalation under ShA and LgA conditions by analyzing intake from the first $1.5 \mathrm{~h}$ of each session from both groups of rats (Ahmed and Koob, 1998); this was done with age and access condition as between-subject factors and session as within-subject factor. As Figure $4 C$ shows, again, adolescents took more cocaine than adults overall (age effect, $F_{(1,18)}=13.04$, $p<0.001$ ); intake changed over time (session effect, $F_{(11,99)}=$ $3.54, p<0.001$ ), and the relationship between age groups and access condition also changed over time (age $\times$ session interaction, $F_{(11,198)}=4.55, p<0.001$; access condition $\times$ session interaction, $\left.F_{(11,198)}=1.84, p<0.05\right)$. Subsequent analysis of each group (separated by age and access condition) revealed a main effect of session only in adolescent rats under $\operatorname{LgA}$ conditions

(adolescent LgA, $F_{(11,44)}=3.38, p<0.01$; adult $\operatorname{LgA}, F_{(11,55)}=$ 1.20 , n.s.; adolescent ShA, $F_{(11,44)}=1.78$, n.s; adult ShA, $F_{(11,55)}=$ 1.65, n.s.). Post hoc tests showed that, for adolescents with LgA, intake increased from session 8 onward relative to session 1 ( $p<$ 0.05 ). Thus, even when only the first $1.5 \mathrm{~h}$ of testing was considered, escalation of cocaine intake was observed in adolescents with LgA but not in adolescents with ShA or in adults under either ShA or LgA conditions.

Experiment 3: age differences in cocaine consumption as a function of price

As Figure $5 A$ shows, adolescents nose poked more than adults for cocaine at a high dose $(1200 \mu \mathrm{g} / \mathrm{kg}$ per infusion). For the active hole, responding increased as the FR requirement (i.e., the price) increased (ratio effect, $F_{(4,68)}=15.55, p<0.001$ ), and this occurred more so for adolescents than adults (Fig. 5; age effect, $F_{(1,17)}=11.38, p<0.01$; age $\times$ ratio interaction, $F_{(4,68)}=2.85$, $p<0.05)$. In particular, adolescents responded more than adults 


\section{A Cocaine (1200 $\mu \mathrm{g} / \mathrm{kg} /$ infusion)}
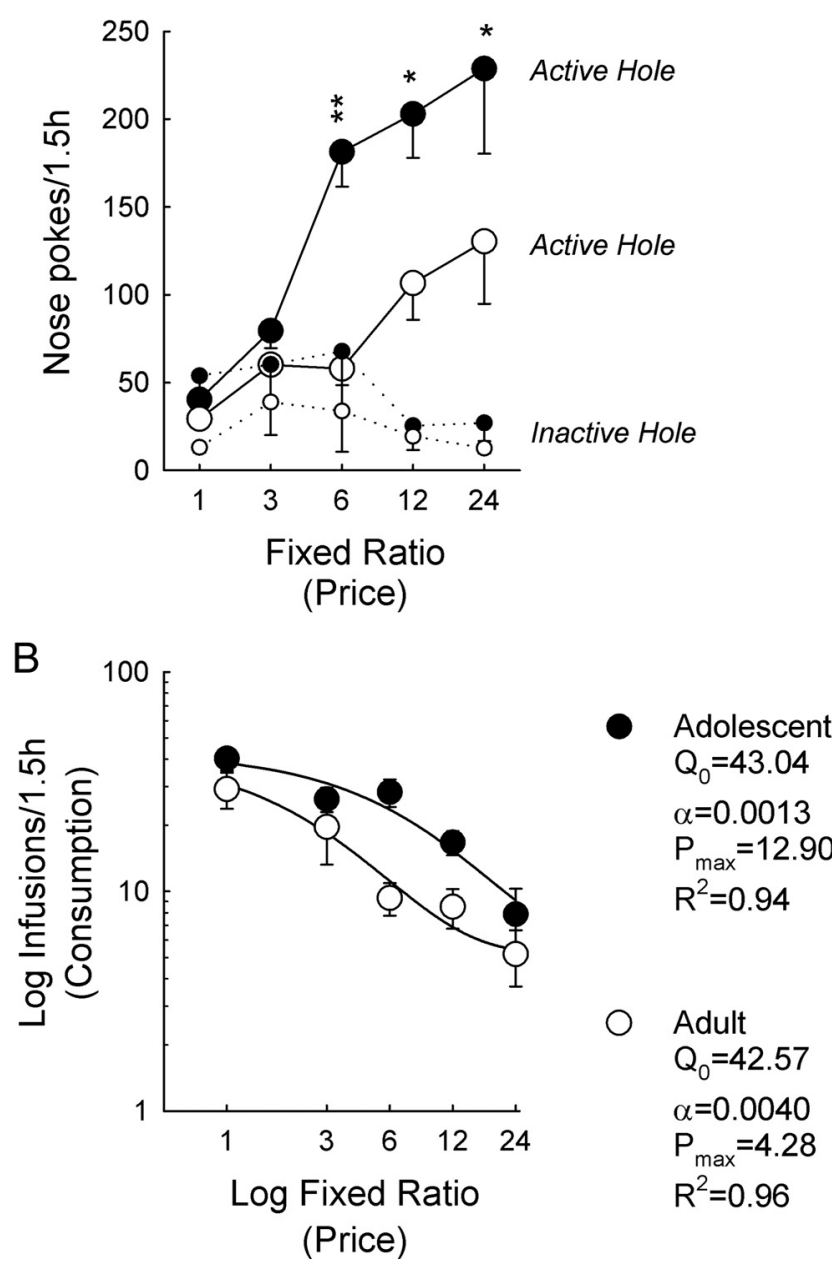

Figure 5. Self-administration of cocaine ( $1200 \mu \mathrm{g} / \mathrm{kg}$ per infusion) as a function of price. $A$, Number of nose pokes when the price of cocaine is increased, by increasing the FR to obtain the drug. $\boldsymbol{B}$, Consumption of cocaine (number of self-infusions) as a function of price (i.e., ratio), plotted on a logarithmic scale and fit according to the exponential demand equation. $Q_{0}$, The level of consumption at the lowest price; $\alpha$, elasticity of cocaine demand; $P_{\text {max }}$ the price at which behavior shifts from inelastic to elastic. $R^{2}$, the square of the coefficient of correlation (i.e., the coefficient of determination) for the curve fit. Each point represents the mean \pm SEM values of each group on the second day for each ratio. Adolescents, $n=7$; adults, $n=12$. ${ }^{*} p<$ $0.05 ;{ }^{* *} p<0.01$ compared with adults.

at high prices (FR6, $p<0.01$; FR12, $p<0.05$; and FR24, $p<0.05$ ) but not at low prices (FR1 and FR3, n.s.). Inactive hole responding did not change as the ratio increased (ratio effect, $F_{(4,68)}=$ 1.77 , n.s.) in either age group (age effect, $F_{(1,17)}=3.04$, n.s.; age $\times$ ratio interaction, $F_{(4,68)}=0.41$, n.s.). Discrimination between the active and inactive hole was manifested robustly as the ratio increased, with discrimination becoming apparent at an earlier stage in adolescents than in adults (hole effect, $F_{(1,17)}=63.09, p<0.001$; ratio $\times$ hole interaction, $F_{(4,68)}=21.10, p<0.001$; ratio $\times$ hole $\times$ age interaction, $\left.F_{(4,68)}=3.71, p<0.01\right)$. Specifically, adolescents discriminated at FR6, FR12, and FR24 $(p<0.05)$, whereas adults discriminated only at FR12 and FR24 $(p<0.05)$.

We analyzed the manner in which consumption (i.e., number of self-infusions) varies as a function of price (i.e., ratio) by fitting the data to the exponential demand curve established by Hursh and Silberberg (2008). Data from both adolescents and adults fit the curve well $\left(R^{2}=0.94\right.$ for adolescents; $R^{2}=0.96$ for adults), and values from these curves are shown in Figure 5B. $Q_{0}$ (maximal con- sumption at the lowest price) was similar across ages $\left(F_{(1,5)}=0.001\right.$, n.s.). Consumption declined as a function of price, and the decline was less steep in adolescents versus adults. That is, adolescents had smaller $\alpha$ than adults $\left(F_{(1,5)}=10.45, p<0.05\right)$, indicating that demand was more inelastic in adolescents than adults.

\section{Experiment 4: age differences on levels of cocaine and its} metabolites in the brain

There was a trend for adolescents to have lower levels of cocaine in blood $\left(923.24 \pm 67.32 \mathrm{vs} 1119.73 \pm 66.94 \mathrm{ng} / \mathrm{ml}, t_{(9)}=-2.05\right.$, $p=0.070)$ but not in brain $(5135.20 \pm 281.25$ vs $6947.00 \pm$ $971.28 \mathrm{ng} / \mathrm{g}, t_{(9)}=-1.64$, n.s.). There was also a trend for adolescents to have lower levels of the cocaine metabolite benzoylecgonine in blood $(754.72 \pm 81.09$ vs $1086.70 \pm 133.07 \mathrm{ng} / \mathrm{ml}$, $\left.t_{(9)}=-2.02, p=0.074\right)$ and in brain (123.30 \pm 13.80 vs $184.38 \pm$ $\left.25.15 \mathrm{ng} / \mathrm{g}, t_{(9)}=-2.00, p=0.076\right)$. There were no significant age differences in levels of the cocaine metabolite ecgoninemethyl-ester in blood $(105.84 \pm 5.08$ vs $87.27 \pm 9.48 \mathrm{ng} / \mathrm{ml}$, $t_{(9)}=1.62$, n.s. $)$ or brain $(138.54 \pm 9.62$ vs $146.44 \pm 5.36 \mathrm{ng} / \mathrm{g}$, $U_{(11)}=14.00, Z=-0.09$, n.s.). There were also no differences in the metabolite norcocaine in blood $(8.28 \pm 0.96$ vs $11.77 \pm 1.72$, $\left.t_{(9)}=-1.67, \mathrm{n} . \mathrm{s}\right)$. Norcocaine levels in brain were undetectable in most samples (data not shown).

\section{In vivo extracellular recording of VTA neurons}

Relative to adults, adolescents exhibited higher firing rates of VTA dopamine neurons by $\sim 1 \mathrm{~Hz}(\sim 24 \%)$ (Fig. $6 A ; t_{(41)}=2.33$; $p<0.05)$. The amount of bursting was similar across ages. This was measured as the percentage of spikes emitted in bursts (Fig. $6 A ; t_{(41)}=0.30 ;$ n.s. $)$ and the frequency of burst events $(0.46 \pm$ 0.08 vs $0.51 \pm 0.09 \mathrm{~Hz}, t_{(41)}=-0.40 ;$ n.s). However, adolescents exhibited larger burst events than adults, with more spikes per burst (Fig. $6 A ; t_{(41)}=2.28 ; p<0.05$ ) and a trend toward longer burst durations $\left(256.76 \pm 35.12\right.$ vs $157.60 \pm 33.40 \mathrm{~ms}, t_{(47)}=$ $2.01, p=0.051)$. As Figure $6 B$ shows, the area of the VTA that was sampled was comparable across ages (age effect, $F_{(1,41)}=2.71$, n.s.; age $\times$ structure interaction, $F_{(2,82)}=0.28$, n.s.). Coordinates (in millimeters) for adolescents versus adults were as follows: anteroposterior, $3.57 \pm 0.04$ vs $3.66 \pm 0.05$; mediolateral, $0.84 \pm 0.05$ vs $0.97 \pm 0.07$; dorsoventral, $7.79 \pm 0.05$ vs $7.84 \pm 0.04$. Results were similar if only the last recorded cell marked with the fast green dye was analyzed (data not shown).

\section{Effects of drugs that modify dopamine neuron activity on cocaine self-administration}

We tested the relationship between dopamine neuron activity and self-administration by pharmacologically modifying dopamine neuron activity and examining its impact on cocaine selfadministration at a moderate dose $(600 \mu \mathrm{g} / \mathrm{kg}$ per infusion). Quinpirole, a $\mathrm{D}_{2}$ receptor agonist, was used to decrease neuron activity, and eticlopride, a $\mathrm{D}_{2}$ receptor antagonist, was used to increase neuron activity (Marinelli et al., 2003). Rats were first trained at FR1 for $2 \mathrm{~d}$ (data not shown); then they were trained at FR3 for 4 additional days. Rats were then divided into three groups with similar cocaine intake (drug effect, $F_{(2,61)}=2.08$, n.s.) that were scheduled to receive saline, quinpirole $(0.2 \mu \mathrm{g} / \mathrm{kg}$, s.c. $)$, or eticlopride $(0.2$ $\mu \mathrm{g} / \mathrm{kg}$, s.c.). As shown in Figure 7, during pretreatment, adolescent versus adult differences in cocaine intake were maintained in all groups (age effect, $F_{(1,61)}=31.08, p<0.001$; drug effect, $F_{(2,61)}=$ 2.08 , n.s.; age $\times$ drug interaction, $F_{(2,61)}=1.68$, n.s.). We then compared behavior before (pretreatment, average of $3 \mathrm{~d}$ before treatment) versus after treatment (posttreatment). This was done using time point (pre vs post) as within-subject factor and age (adolescents 

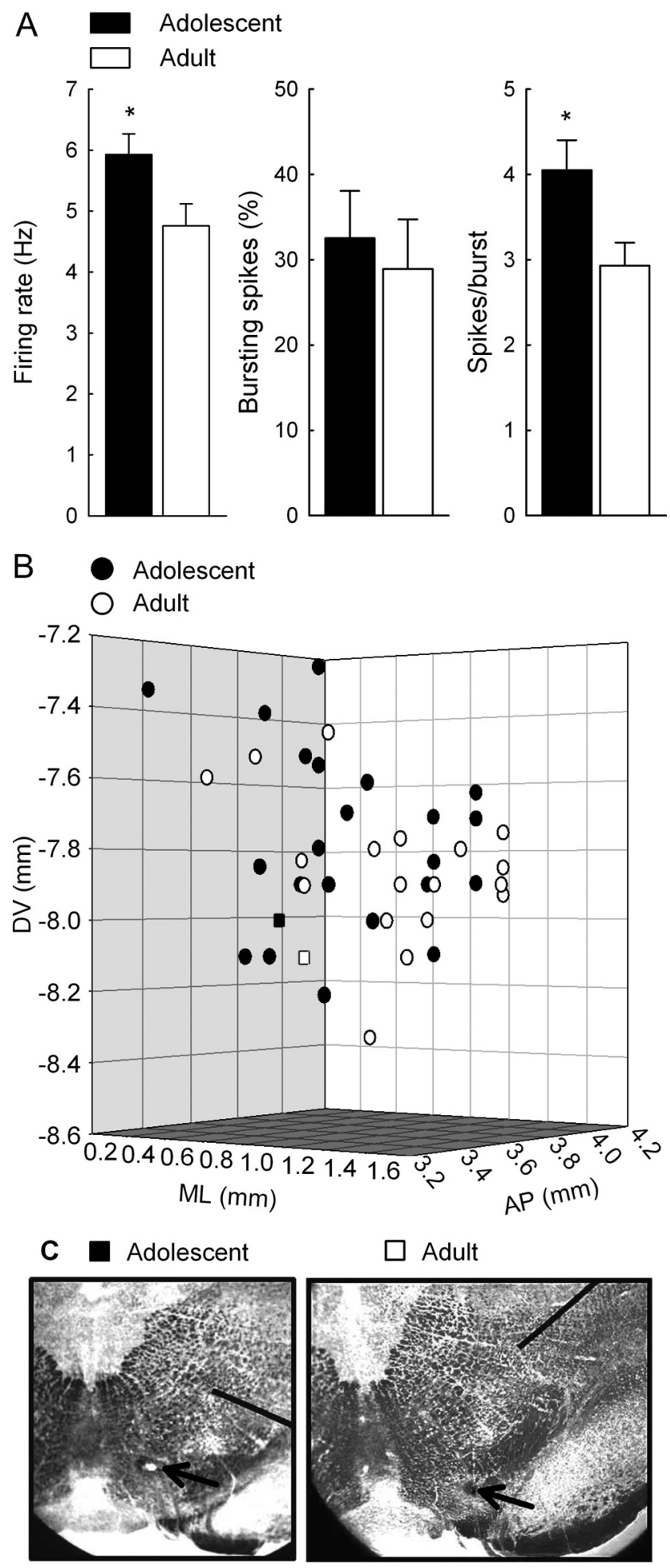

Figure 6. A, Activity of dopamine neurons. Left, Firing rate; middle, bursting spikes (per(entage); right, spikes per burst. Each vertical bar represents mean \pm SEM of each group. Adolescents, $n=24$ cells from 11 rats; adults, $n=19$ cells from 11 rats. ${ }^{*} p<0.05$ compared with adults. $\boldsymbol{B}$, Location of dopamine neurons sampled in the VTA. Locations (in millimeters) are anteroposterior from lambda (AP), mediolateral from the midline (ML), and dorsoventral from the surface of the cortex (DV). Each circle/square represents the location of a single dopamine neuron. $\boldsymbol{C}$, Representative histological images from cells represented by squares in $\boldsymbol{B}$. Electrode placement is marked with a black arrow. The black line is a reference marker and is part of the ocular piece of the microscope.

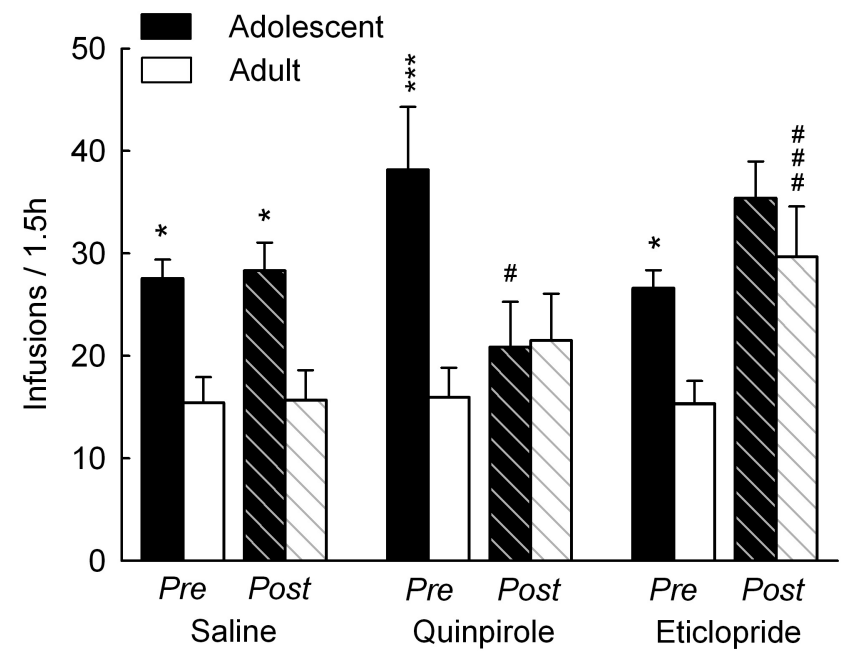

Figure 7. Cocaine self-administration at a moderate dose (600 $\mu \mathrm{g} / \mathrm{kg}$ per infusion) before (Pre) and after (Post) administration of drugs that modify dopamine neuron activity. Each vertical bar represents the mean \pm SEM infusions/1.5 h of each group. Pre values are average during the $3 \mathrm{~d}$ before drug administration. Post values are immediately after drug administration. Adolescents, $n=$ 11,12 , and 11 for saline, quinpirole, and eticlopride, respectively; adults, $n=11$ in each group. ${ }^{*} p<$ 0.05 ; $^{* * *} p<0.001$ compared with adults. ${ }^{\#}<<0.05 ;{ }^{\# \# \#} p<0.001$ compared with Pre.

vs adults) and drug (saline, quinpirole, eticlopride) as betweensubject factors. Behavior changed according to the drug that was administered (drug $\times$ time-point interaction: $F_{(2,61)}=14,43, p<$ $0.001)$ and the age of the subjects (age $\times$ time-point interaction, $F_{(1,61)}=11.96, p<0.001$; age $\times$ drug $\times$ time-point interaction, $\left.F_{(2,61)}=6.84, p<0.01\right)$. Specifically, saline treatment had no effect on either age group such that adolescents maintained higher cocaine intake than adults (for posttreatment, adolescents vs adults, $p<$ 0.05; pretreatment vs posttreatment, n.s.). Quinpirole suppressed cocaine intake in adolescents, making adolescents "adult-like" (for posttreatment, adolescents vs adults, n.s.; adolescents pretreatment vs adolescents posttreatment, $p<0.05$ ). Eticlopride increased cocaine intake in adults, making them "adolescent-like" (for posttreatment, adolescents vs adults, n.s.; adults pretreatment vs adults posttreatment, $p<0.001$ ). To ensure that the effect of quinpirole was not an artifact of the high baseline (pre-quinpirole) behavior of adolescents, we repeated our analysis after excluding three adolescent rats with high baseline intake in this group. Results were similar, even with these rats removed (data not shown).

\section{Discussion}

Our results show that, relative to adults, adolescents show greater intake of cocaine, acquire cocaine self-administration more rapidly, exhibit escalation of cocaine intake, work harder for the drug and are less sensitive to increases in price (i.e., are more inelastic). Moreover, elevated cocaine self-administration was associated with elevated activity of VTA dopamine neurons and could be reversed with quinpirole, a drug that suppresses the activity of these neurons.

Compared with adults, adolescents showed greater intake of cocaine at low-to-moderate doses ( $150-600 \mu \mathrm{g} / \mathrm{kg}$ per infusion). Elevated cocaine intake was seen when rats were given either ShA or LgA to cocaine, suggesting that the difference between adolescents and adults was not an artifact of insufficient sampling time. Our results are in line with two studies showing that adolescents self-administer more cocaine than adults at a moderately low dose $[400 \mu \mathrm{g} / \mathrm{kg}$ per infusion (Anker and Carroll, 2010)] or a moderately high dose $[800 \mu \mathrm{g} / \mathrm{kg}$ per infusion (Schramm-Sapyta 
et al., 2011)]. We extended this work by using a wider range of doses, which allows us to determine that adolescents are more sensitive than adults to cocaine. Acquisition of cocaine intake at similar low-moderate doses can be used to test for differences in sensitivity to the rewarding effects of cocaine (Piazza et al., 1989).

Behavioral differences were specific to cocaine because there were no age differences in responding for saline. Similarly, differences were not seen at a very low dose of cocaine $(75 \mu \mathrm{g} / \mathrm{kg}$ per infusion), which may be below the threshold for rats to acquire self-administration. At the high dose (1200 $\mu \mathrm{g} / \mathrm{kg}$ per infusion), adolescents and adults did not differ in cocaine intake. This was expected because differences in sensitivity to drugs are not observed at such high doses (Piazza et al., 2000). This finding is also consistent with studies that did not show greater intake in adolescents versus adults using high cocaine doses (Kantak et al., 2007; Kerstetter and Kantak, 2007).

In humans, onset of puberty is suggested to coincide with onset of substance abuse (Patton et al., 2004). Here, we found that the elevation in cocaine self-administration occurred only in adolescent rats in which puberty had occurred, not before. This highlights postpubertal adolescence as a vulnerable "window" for cocaine addiction. This may help explain why some studies using younger adolescent rats did not find intake differences between adolescents and adults (Leslie et al., 2004; Belluzzi et al., 2005; Frantz et al., 2007; Kantak et al., 2007; Kerstetter and Kantak, 2007; Harvey et al., 2009; Li and Frantz, 2009). Dissimilarities in experimental manipulations could also factor into other discrepancies. For instance, two studies that found no differences in adolescent and adult cocaine intake (Leslie et al., 2004; Belluzzi et al., 2005) were performed during the inactive, rather than the active, phase of the light/dark cycle. In addition, in the abovementioned studies, rats were singly housed instead of group housed. We chose to group house adolescent rats because adolescence is characterized by strong social interactions and play behavior (Spear and Brake, 1983; Vanderschuren et al., 1997; Douglas et al., 2004). Another important factor could be weaning age, which influences experimental outcomes (Wiley and Evans, 2009). Rats purchased through commercial vendors are weaned at any time from P17 to P24 (Harlan) or P19 to P23 (Charles River). We requested that weaning occurred exactly on P21 to prevent unwanted effects from weaning variability.

Cocaine intake escalated in postpubertal adolescents but not in adults. Escalation models a phenomenon in addicts when drug consumption transitions from steady to excessive use (Ahmed, 2011). This type of behavior is a marker for drug dependence according to the Diagnostic and Statistical Manual of Mental Disorders, Edition IV (American Psychiatric Association 2000). Hence, greater escalation in adolescents than in adults is an additional indicator of greater addiction liability. Consistent with this, a recent study showed that adolescents, but not adults, escalated their intake of cocaine or methamphetamine (Anker et al., 2012; Zlebnik et al., 2012). There are several possible reasons why we did not observe escalation in adults. The most likely factor is that long $(\sim 10 \mathrm{~d})$ training is necessary for subsequent development of escalation (Ahmed et al., 2000; Knackstedt and Kalivas, 2007; Ahmed, 2011). Given the limited duration of adolescence, we were confined to short training $(4 \mathrm{~d})$, which may have prevented escalation in adults. Furthermore, escalation is strain and substrain dependent (Freeman et al., 2009; Picetti et al., 2010); it is robust in Long-Evans (Quadros and Miczek, 2009), Wistar (Ahmed and Koob, 1998), and Sprague Dawley rats purchased from Harlan (Ferrario et al., 2005; Mantsch et al., 2008) but appears less robust in Sprague Dawley rats purchased from Charles
River (Knackstedt and Kalivas, 2007; Kelamangalath and Wagner, 2010), which we used in this study.

Another feature of addiction is that addicts spend much time and effort to obtain drugs (American Psychiatric Association 2000) and that their consumption is insensitive to increases in price (Bickel et al., 2011). We modeled this by measuring the amount of work rats would do to obtain cocaine under a progressive increase in cocaine price (Griffiths et al., 1978; Risner and Silcox, 1981). We also evaluated the manner in which consumption varies as a function of price by fitting our data to an exponential demand curve (Bickel et al., 2000; Hursh and Silberberg, 2008). Our studies show that postpubertal adolescents worked more than adults to obtain cocaine. Furthermore, their cocaine consumption was less sensitive to increases in price (i.e., their behavior was more inelastic). Together, these findings suggest that adolescents exhibit behavioral traits of addiction.

What are the mechanisms underpinning increased addiction liability in adolescents? The adolescent brain undergoes extensive organizational and functional changes, including changes in the mesolimbic dopamine system (Andersen et al., 1997; Spear, 2000; Wahlstrom et al., 2010). We have shown previously that activity of VTA dopamine neurons peaks during adolescence (McCutcheon and Marinelli, 2009; McCutcheon et al., 2012). Here, we replicated these findings using a different substrain of rats (Crl:Sprague Dawley from Charles River in the current study vs Hsd:Sprague Dawley from Harlan in the previous study); we found that the activity of dopamine neurons in adolescent rats is $\sim 24 \%$ higher than activity in adults. In another putative model of addiction vulnerability- high-responder vs low-responder rats—a similar increase in dopamine neuron activity was shown to be associated with increased self-administration behavior (Marinelli and White, 2000; McCutcheon et al., 2009). Such heightened activity of the dopamine system may predispose adolescents to drug abuse (Doremus-Fitzwater et al., 2010). We sought to establish causality between drug intake and dopamine neuron activity by manipulating dopamine neuron activity with either $\mathrm{D}_{2}$ receptor agonist, to decrease activity, or an antagonist, to increase activity. By administering these drugs, we reversed age differences in cocaine intake, suggesting that behavioral differences depended on dopamine neuron activity. This suggests a causal link between our neurophysiological and behavioral findings and uncovers a possible mechanism for therapeutic targets. Systemic delivery of pharmacological agents could have pitfalls; however, we chose an autoreceptor-selective dose, which acts centrally at dopamine neuron bodies (Pucak and Grace, 1991). The dose we chose is comparable with doses used by us and others to produce changes in dopamine neuron firing, dopamine release, and behavior (Robertson et al., 1993; Marinelli et al., 2003; Zeeb et al., 2009). It is unlikely that the dose of quinpirole we used significantly activated postsynaptic $\mathrm{D}_{2}$-class receptors, because activation of these receptors increases, rather than decreases, drug intake (Howell et al., 1997).

Some studies suggest that cocaine levels in the brain are similar between adolescents and adults after intraperitoneal or intravenous delivery (Caster et al., 2005; Frantz et al., 2007; Schramm-Sapyta et al., 2011). Our results suggest that levels of cocaine and cocaine metabolites are slightly lower in adolescents than in adults. However, it is unlikely that differences in cocaine levels or metabolism account for the greater cocaine intake by adolescents. Relative to adults, adolescents showed higher intake of a high dose of cocaine when the price to obtain the drug was increased, but they had similar intake at a low price (FR1). Any metabolism-related compensatory increase in cocaine intake would have been seen at both low and high prices. 
Maturational changes in cognitive and behavioral measures may also participate in age-related differences in cocaine selfadministration. Adolescents are considered "risk-takers" and show higher preference for and exploration of novel environments than adults (Douglas et al., 2003; Stansfield and Kirstein, 2006). It has been suggested that risk-taking in adolescents stems from a mismatch between novelty and sensation seeking (which increases at adolescence) and self-regulation (which matures on adulthood) (Steinberg, 2004). Similarly convincing evidence suggests that refinement of inhibitory control as animals mature may explain reduced risk-taking behavior (Ridderinkhof and van der Molen, 1997; Geier et al., 2010) and greater behavioral inhibition (Sturman et al., 2010; Andrzejewski et al., 2011) during adulthood than during adolescence. Although we did not test these traits here, these factors could contribute to the elevated addiction risk in adolescents.

Together, our findings show that postpubertal adolescents are more susceptible than adults to the addictive properties of cocaine. In addition, this heightened addiction liability in adolescence is associated with heightened activity of VTA dopamine neurons and can be reversed by a drug that suppresses the activity of these neurons. Therefore, our findings provide insight into neural mechanisms of adolescent addiction liability by highlighting dopamine neurons as a key element of addiction risk. Our findings also indicate that heightened susceptibility to cocaine addiction is a product of adolescent neurobiology and can be demonstrated in the absence of external social and economic influences. Therefore, therapeutic strategies that target biological risk factors during adolescence should be given high priority, because adolescence confers such strong susceptibility to addictive behavior.

\section{References}

Ahmed S (2011) Escalation of drug use. In: Animal models of drug addiction, Neuromethods (Olmstead M, ed). New York: Humana.

Ahmed SH, Koob GF (1998) Transition from moderate to excessive drug intake: change in hedonic set point. Science 282:298-300. CrossRef Medline

Ahmed SH, Walker JR, Koob GF (2000) Persistent increase in the motivation to take heroin in rats with a history of drug escalation. Neuropsychopharmacology 22:413-421. CrossRef Medline

American Psychiatric Association (2000) Diagnostic and statistical manual of mental disorders, Ed 4, Text Revision Edition. Washington, DC: American Psychiatric Association.

Andersen SL, Rutstein M, Benzo JM, Hostetter JC, Teicher MH (1997) Sex differences in dopamine receptor overproduction and elimination. Neuroreport 8:1495-1498. CrossRef Medline

Andrzejewski ME, Schochet TL, Feit EC, Harris R, McKee BL, Kelley AE (2011) A comparison of adult and adolescent rat behavior in operant learning, extinction, and behavioral inhibition paradigms. Behav Neurosci 125:93-105. CrossRef Medline

Anker JJ, Carroll ME (2010) Reinstatement of cocaine seeking induced by drugs, cues, and stress in adolescent and adult rats. Psychopharmacology (Berl) 208:211-222. CrossRef Medline

Anker JJ, Baron TR, Zlebnik NE, Carroll ME (2012) Escalation of methamphetamine self-administration in adolescent and adult rats. Drug Alcohol Depend 124:149-153. CrossRef Medline

Anthony JC, Petronis KR (1995) Early-onset drug use and risk of later drug problems. Drug Alcohol Depend 40:9-15. CrossRef Medline

Belluzzi JD, Wang R, Leslie FM (2005) Acetaldehyde enhances acquisition of nicotine self-administration in adolescent rats. Neuropsychopharmacology 30:705-712. CrossRef Medline

Bickel WK, Marsch LA, Carroll ME (2000) Deconstructing relative reinforcing efficacy and situating the measures of pharmacological reinforcement with behavioral economics: a theoretical proposal. Psychopharmacology (Berl) 153:44-56. CrossRef Medline

Bickel WK, Jarmolowicz DP, Mueller ET, Gatchalian KM (2011) The behavioral economics and neuroeconomics of reinforcer pathologies: implications for etiology and treatment of addiction. Curr Psychiatry Rep 13:406-415. CrossRef Medline
Bunney BS, Walters JR, Roth RH, Aghajanian GK (1973) Dopaminergic neurons: effect of antipsychotic drugs and amphetamine on single cell activity. J Pharmacol Exp Ther 185:560-571. Medline

Cassidy RN, Dallery J (2012) Effects of economy type and nicotine on the essential value of food in rats. J Exp Anal Behav 97:183-202. CrossRef Medline

Caster JM, Walker QD, Kuhn CM (2005) Enhanced behavioral response to repeated-dose cocaine in adolescent rats. Psychopharmacology (Berl) 183:218-225. CrossRef Medline

Chambers RA, Taylor JR, Potenza MN (2003) Developmental neurocircuitry of motivation in adolescence: a critical period of addiction vulnerability. Am J Psychiatry 160:1041-1052. CrossRef Medline

Chen CY, Storr CL, Anthony JC (2009) Early-onset drug use and risk for drug dependence problems. Addict Behav 34:319-322. CrossRef Medline

Doremus TL, Brunell SC, Rajendran P, Spear LP (2005) Factors influencing elevated ethanol consumption in adolescent relative to adult rats. Alcohol Clin Exp Res 29:1796-1808. CrossRef Medline

Doremus-Fitzwater TL, Varlinskaya EI, Spear LP (2010) Motivational systems in adolescence: possible implications for age differences in substance abuse and other risk-taking behaviors. Brain Cogn 72:114-123. CrossRef Medline

Douglas LA, Varlinskaya EI, Spear LP (2003) Novel-object place conditioning in adolescent and adult male and female rats: effects of social isolation. Physiol Behav 80:317-325. CrossRef Medline

Douglas LA, Varlinskaya EI, Spear LP (2004) Rewarding properties of social interactions in adolescent and adult male and female rats: impact of social versus isolate housing of subjects and partners. Dev Psychobiol 45:153162. CrossRef Medline

Ferrario CR, Gorny G, Crombag HS, Li Y, Kolb B, Robinson TE (2005) Neural and behavioral plasticity associated with the transition from controlled to escalated cocaine use. Biol Psychiatry 58:751-759. CrossRef Medline

Frantz KJ, O'Dell LE, Parsons LH (2007) Behavioral and neurochemical responses to cocaine in periadolescent and adult rats. Neuropsychopharmacology 32:625-637. CrossRef Medline

Freeman KB, Kearns DN, Kohut SJ, Riley AL (2009) Strain differences in patterns of drug-intake during prolonged access to cocaine selfadministration. Behav Neurosci 123:156-164. CrossRef Medline

Geier CF, Terwilliger R, Teslovich T, Velanova K, Luna B (2010) Immaturities in reward processing and its influence on inhibitory control in adolescence. Cereb Cortex 20:1613-1629. CrossRef Medline

Grace AA, Bunney BS (1983) Intracellular and extracellular electrophysiology of nigral dopaminergic neurons. 1. Identification and characterization. Neuroscience 10:301-315. CrossRef Medline

Grace AA, Bunney BS (1984) The control of firing pattern in nigral dopamine neurons: single spike firing. J Neurosci 4:2866-2876. Medline

Griffiths RR, Brady JV, Snell JD (1978) Progressive-ratio performance maintained by drug infusions: comparison of cocaine, diethylpropion, chlorphentermine, and fenfluramine. Psychopharmacology (Berl) 56:5-13. CrossRef Medline

Harvey RC, Dembro KA, Rajagopalan K, Mutebi MM, Kantak KM (2009) Effects of self-administered cocaine in adolescent and adult male rats on orbitofrontal cortex-related neurocognitive functioning. Psychopharmacology (Berl) 206:61-71. CrossRef Medline

Howell LL, Czoty PW, Byrd LD (1997) Pharmacological interactions between serotonin and dopamine on behavior in the squirrel monkey. Psychopharmacology (Berl) 131:40-48. CrossRef Medline

Hursh SR (1993) Behavioral economics of drug self-administration: an introduction. Drug Alcohol Depend 33:165-172. CrossRef Medline

Hursh SR, Roma PG (2013) Behavioral economics and emperical public policy. J Exp Anal Behav 99:98-124. CrossRef Medline

Hursh SR, Silberberg A (2008) Economic demand and essential value. Psychol Rev 115:186-198. CrossRef Medline

Johnston LD, O’Malley PM, Bachman JG, Schulenberg JE (2011) Monitoring the future national results on adolescent drug use: overview of key findings, 2010. Ann Arbor, MI: Institute for Social Research, The University of Michigan.

Kandel DB, Yamaguchi K, Chen K (1992) Stages of progression in drug involvement from adolescence to adulthood: further evidence for the gateway theory. J Stud Alcohol 53:447-457. Medline

Kantak KM, Goodrich CM, Uribe V (2007) Influence of sex, estrous cycle, 
and drug-onset age on cocaine self-administration in rats (Rattus norvegicus). Exp Clin Psychopharmacol 15:37-47. CrossRef Medline

Kelamangalath L, Wagner JJ (2010) D-serine treatment reduces cocaineprimed reinstatement in rats following extended access to cocaine selfadministration. Neuroscience 169:1127-1135. CrossRef Medline

Kerstetter KA, Kantak KM (2007) Differential effects of self-administered cocaine in adolescent and adult rats on stimulus-reward learning. Psychopharmacology (Berl) 194:403-411. CrossRef Medline

Knackstedt LA, Kalivas PW (2007) Extended access to cocaine selfadministration enhances drug-primed reinstatement but not behavioral sensitization. J Pharmacol Exp Ther 322:1103-1109. CrossRef Medline

Kolho KL, Nikula H, Huhtaniemi I (1988) Sexual maturation of male rats treated postnatally with a gonadotrophin-releasing hormone antagonist. J Endocrinol 116:241-246. CrossRef Medline

Leslie FM, Loughlin SE, Wang R, Perez L, Lotfipour S, Belluzzia JD (2004) Adolescent development of forebrain stimulant responsiveness: insights from animal studies. Ann N Y Acad Sci 1021:148-159. CrossRef Medline

Levin ED, Lawrence SS, Petro A, Horton K, Rezvani AH, Seidler FJ, Slotkin TA (2007) Adolescent vs. adult-onset nicotine self-administration in male rats: duration of effect and differential nicotinic receptor correlates. Neurotoxicol Teratol 29:458-465. CrossRef Medline

Li C, Frantz KJ (2009) Attenuated incubation of cocaine seeking in male rats trained to self-administer cocaine during periadolescence. Psychopharmacology (Berl) 204:725-733. CrossRef Medline

Lin SN, Moody DE, Bigelow GE, Foltz RL (2001) A validated liquid chromatography-atmospheric pressure chemical ionization-tandem mass spectrometry method for quantitation of cocaine and benzoylecgonine in human plasma. J Anal Toxicol 25:497-503. Medline

Lin SN, Walsh SL, Moody DE, Foltz RL (2003) Detection and time course of cocaine $\mathrm{N}$-oxide and other cocaine metabolites in human plasma by liquid chromatography/tandem mass spectrometry. Anal Chem 75:4335-4340. CrossRef Medline

Lynch WJ, Carroll ME (2001) Regulation of drug intake. Exp Clin Psychopharmacol 9:131-143. CrossRef Medline

Mantsch JR, Yuferov V, Mathieu-Kia AM, Ho A, Kreek MJ (2004) Effects of extended access to high versus low cocaine doses on self-administration, cocaine-induced reinstatement and brain mRNA levels in rats. Psychopharmacology (Berl) 175:26-36. CrossRef Medline

Mantsch JR, Baker DA, Francis DM, Katz ES, Hoks MA, Serge JP (2008) Stressor- and corticotropin releasing factor-induced reinstatement and active stress-related behavioral responses are augmented following longaccess cocaine self-administration by rats. Psychopharmacology (Berl) 195:591-603. CrossRef Medline

Marinelli M, White FJ (2000) Enhanced vulnerability to cocaine selfadministration is associated with elevated impulse activity of midbrain dopamine neurons. J Neurosci 20:8876-8885. Medline

Marinelli M, Cooper DC, Baker LK, White FJ (2003) Impulse activity of midbrain dopamine neurons modulates drug-seeking behavior. Psychopharmacology (Berl) 168:84-98. CrossRef Medline

Marinelli M, Rudick CN, Hu XT, White FJ (2006) Excitability of dopamine neurons: modulation and physiological consequences. CNS Neurol Disord Drug Targets 5:79-97. CrossRef Medline

McCutcheon JE, Marinelli M (2009) Age matters. Eur J Neurosci 29:9971014. CrossRef Medline

McCutcheon JE, White FJ, Marinelli M (2009) Individual differences in dopamine cell neuroadaptations following cocaine self-administration. Biol Psychiatry 66:801-803. CrossRef Medline

McCutcheon JE, Conrad KL, Carr SB, Ford KA, McGehee DS, Marinelli M (2012) Dopamine neurons in the ventral tegmental area fire faster in adolescent rats than in adults. J Neurophysiol 108:1620-1630. CrossRef Medline

Mitchell JM, Cunningham CL, Mark GP (2005) Locomotor activity predicts acquisition of self-administration behavior but not cocaine intake. Behav Neurosci 119:464-472. CrossRef Medline

Patton GC, McMorris BJ, Toumbourou JW, Hemphill SA, Donath S, Catalano RF (2004) Puberty and the onset of substance use and abuse. Pediatrics 114:e300-e306. CrossRef Medline

Piazza PV, Deminière JM, Le Moal M, Simon H (1989) Factors that predict individual vulnerability to amphetamine self-administration. Science 245:1511-1513. CrossRef Medline

Piazza PV, Deroche-Gamonent V, Rouge-Pont F, Le Moal M (2000) Vertical shifts in self-administration dose-response functions predict a drug- vulnerable phenotype predisposed to addiction. J Neurosci 20:4226-4232. Medline

Picetti R, Ho A, Butelman ER, Kreek MJ (2010) Dose preference and dose escalation in extended-access cocaine self-administration in Fischer and Lewis rats. Psychopharmacology (Berl) 211:313-323. CrossRef Medline

Pucak ML, Grace AA (1991) Partial dopamine depletions result in an enhanced sensitivity of residual dopamine neurons to apomorphine. Synapse 9:144-155. CrossRef Medline

Quadros IM, Miczek KA (2009) Two modes of intense cocaine bingeing: increased persistence after social defeat stress and increased rate of intake due to extended access conditions in rats. Psychopharmacology (Berl) 206:109-120. CrossRef Medline

Reboussin BA, Anthony JC (2006) Is there epidemiological evidence to support the idea that a cocaine dependence syndrome emerges soon after onset of cocaine use? Neuropsychopharmacology 31:2055-2064. CrossRef Medline

Ridderinkhof KR, van der Molen MW (1997) Mental resources, processing speed, and inhibitory control: a developmental perspective. Biol Psychol 45:241-261. CrossRef Medline

Risner ME, Silcox DL (1981) Psychostimulant self-administration by beagle dogs in a progressive-ratio paradigm. Psychopharmacology (Berl) 75:25-30. CrossRef Medline

Robertson GS, Tham CS, Wilson C, Jakubovic A, Fibiger HC (1993) In vivo comparisons of the effects of quinpirole and the putative presynaptic dopaminergic agonists B-HT 920 and SND 919 on striatal dopamine and acetylcholine release. J Pharmacol Exp Ther 264:1344-1351. Medline

Schramm-Sapyta NL, Walker QD, Caster JM, Levin ED, Kuhn CM (2009) Are adolescents more vulnerable to drug addiction than adults? Evidence from animal models. Psychopharmacology (Berl) 206:1-21. CrossRef Medline

Schramm-Sapyta NL, Cauley MC, Stangl DK, Glowacz S, Stepp KA, Levin ED, Kuhn CM (2011) Role of individual and developmental differences in voluntary cocaine intake in rats. Psychopharmacology (Berl) 215:493-504. CrossRef Medline

Shahbazi M, Moffett AM, Williams BF, Frantz KJ (2008) Age- and sexdependent amphetamine self-administration in rats. Psychopharmacology (Berl) 196:71-81. CrossRef Medline

Siegmund S, Vengeliene V, Singer MV, Spanagel R (2005) Influence of age at drinking onset on long-term ethanol self-administration with deprivation and stress phases. Alcohol Clin Exp Res 29:1139-1145. CrossRef Medline

Spear LP (2000) The adolescent brain and age-related behavioral manifestations. Neurosci Biobehav Rev 24:417-463. CrossRef Medline

Spear LP, Brake SC (1983) Periadolescence: age-dependent behavior and psychopharmacological responsivity in rats. Dev Psychobiol 16:83-109. CrossRef Medline

Stansfield KH, Kirstein CL (2006) Effects of novelty on behavior in the adolescent and adult rat. Dev Psychobiol 48:10-15. CrossRef Medline

Steinberg L (2004) Risk taking in adolescence: what changes, and why? Ann N Y Acad Sci 1021:51-58. CrossRef Medline

Sturman DA, Mandell DR, Moghaddam B (2010) Adolescents exhibit behavioral differences from adults during instrumental learning and extinction. Behav Neurosci 124:16-25. CrossRef Medline

Twining RC, Bolan M, Grigson PS (2009) Yoked delivery of cocaine is aversive and protects against the motivation for drug in rats. Behav Neurosci 123:913-925. CrossRef Medline

Ungless MA, Grace AA (2012) Are you or aren't you? Challenges associated with physiologically identifying dopamine neurons. Trends Neurosci 35: 422-430. CrossRef Medline

Vanderschuren LJ, Niesink RJ, Van Ree JM (1997) The neurobiology of social play behavior in rats. Neurosci Biobehav Rev 21:309-326. CrossRef Medline

Wahlstrom D, Collins P, White T, Luciana M (2010) Developmental changes in dopamine neurotransmission in adolescence: behavioral implications and issues in assessment. Brain Cogn 72:146-159. CrossRef Medline

Wiley JL, Evans RL (2009) To breed or not to breed? Empirical evaluation of drug effects in adolescent rats. Int J Dev Neurosci 27:9-20. CrossRef Medline

Zeeb FD, Robbins TW, Winstanley CA (2009) Serotonergic and dopaminergic modulation of gambling behavior as assessed using a novel rat 
gambling task. Neuropsychopharmacology 34:2329-2343. CrossRef Medline

Zlebnik NE, Anker JJ, Carroll ME (2012) Exercise to reduce the escalation of cocaine self-administration in adolescent and adult rats. Psychopharmacology (Berl) 224:387-400. CrossRef Medline 